\title{
Upstream Supply Chain Visibility and Complexity Effect on Focal Company's Sustainable Performance: Indian Manufacturers' Perspective
}

\author{
Rameshwar Dubey \\ Montpellier Business School \\ Montpellier Research in Management \\ 2300 Avenue des Moulins \\ 34000 Montpellier France \\ E-mail: rameshwardubey@gmail.com \\ Angappa Gunasekaran* \\ Charlton College of Business \\ University of Massachusetts Dartmouth \\ North Dartmouth, MA 02747-2300 \\ USA \\ Tel: (508) 999-9187 \\ Fax: (508) 999-8646 \\ E-mail: agunasekaran@umassd.edu \\ Stephen J. Childe \\ Plymouth Business School \\ Plymouth University \\ Plymouth, PL4 8AA \\ United Kingdom \\ E-mail: stephen.childe@plymouth.ac.uk \\ Thanos Papadopoulos \\ Kent Business School \\ University of Kent \\ Sail and Colour Loft, The Historic Dockyard \\ Chatham, Kent ME4 4TE \\ United Kingdom \\ E-mail: A.Papadopoulos@kent.ac.uk
}

Zongwei Luo

Computer Science \& Engineering

South University of Science and Technology of China

1088 Xueyuan Blvd., Shenzen, Guangdong, China, 518055

E-mail:luozw@sustc.edu.cn

David ROUBAUD

Montpellier Business School

Montpellier Research in Management

2300 Avenue des Moulins

34000 Montpellier France

E-mail: d.roubaud@montpellier-bs.com 


\title{
Upstream Supply Chain Visibility and Complexity Effect on Focal Company's Sustainable Performance: Indian Manufacturers' Perspective
}

\begin{abstract}
Understanding supply chain sustainability performance is increasingly important for supply chain researchers and managers. Literature has considered supply chain sustainability and the antecedents of performance from a triple bottom line (economic, social, and environmental) perspective. However, the role of supply chain visibility and product complexity contingency in achieving sustainable supply chain performance has not been explored in depth. To address this gap, this study utilizes a contingent resource-based view theory perspective to understand the role of product complexity in shaping the relationship between upstream supply chain visibility (resources and capabilities) and the social, environmental, and economic performance dimensions. We develop and test a theoretical model using survey data gathered from 312 Indian manufacturing organizations. Our findings indicate that supply chain visibility (SCV) has significant influence on social and environmental performance under the moderation effect of product complexity. Hence, the study makes significant contribution to the extant literature by examining the impact of SCV under moderating effect of product complexity on social performance and environmental performance.
\end{abstract}

Keywords: sustainable supply chain, supply chain performance, contingent resource based view, connectivity, information sharing, visibility, product complexity, factor analysis, regression analysis. 


\section{Introduction}

Sustainable supply chain management (SSCM) remains a key management perspective that affects supply chain performance (Marshall et al. 2015; Jabbour et al. 2012, 2015; Brandenburg and Rebs, 2015; Fahimnia et al. 2017). In a recent study, Kumar et al. (2016) defined sustainable supply chain as the integration of environmental, social and economic aspects in the supply chain. Despite the increased attention from both academia and industry, achieving sustainable supply chain performance remains a challenge. No matter if characteristics such as tighter coupling, increased complexities, reduced inventory levels, outsourcing, and ever-greater geographic dispersion have helped firms to reduce their supply chain costs, they have created greater vulnerabilities in the form of rapid change in climate and social-economic disparities (Hall and Matos, 2010; Bode et al. 2011; Kaur and Singh, 2016). Failures in implementing supply chain sustainability have occurred in the past; for instance, the fire in one of the leading suppliers of Wal-Mart, a Bangladesh garment factory, where more than 1, 130 people died (The Guardian, 2013), due to a lack of proper understanding of sustainable supply chain design. Thus, many organizations, including Nestle, ITC, Unilever, Toyota and others are seriously paying attention to their upstream suppliers to create sustainable supply chains to generate profit for the organizations while reducing environmental impacts and improving the quality of working life of their employees.

Wu and Pagell (2011) argue that in sustainable supply chains organizations need to consider and address the uncertainty that surrounds environmental decisions (Song et al. 2016), the environmental issues due to the number of entities in the chain, and the interconnectedness of supply chain and ecological systems due to lack of visibility in the supply chain network. Supply chain visibility has been noted as an important organizational capability (see Barratt and Oke, 2007; Juttner and Maklan, 2011; Brandon-Jones et al. 2014). It may improve coordination between 
supply chain partners (Arshinder et al. 2008; Carter and Rogers, 2008; Kannan et al. 2014; Lehoux et al. 2014; Maghsoudi and Pazirandeh, 2016; Akhavan and Beckmann, 2017), information sharing (Mabert and Venkataramanan, 1998) and performance, by reducing the negative consequences of distortions (Lee et al., 2000). Furthermore, supply chain visibility allows organizations to be more agile (Christopher, 2000) and creates strategic value (Wei and Wang, 2010). Barratt and Oke (2007) regard information sharing as an antecedent of supply chain visibility. Holcomb et al. (2011) argue that supply chain visibility relies on shared data and information, whereas Brandon-Jones et al. (2014) argue that supply chain connectivity and information sharing are the immediate antecedents of supply chain visibility. In this study 'supply chain connectivity' relates to the technological infrastructure to share information among supply chain network partners (Zhu and Kraemer, 2002) and "information sharing" relates to the nature, speed, and quality of information being shared (Cao and Zhang, 2011; Brandon-Jones et al. 2014). Both form the basis of supply chain visibility.

However, Francis (2008) argues that supply chain visibility is often misunderstood. Barratt and Oke (2007) have noted that prior research has failed to delineate between information sharing and supply chain visibility. Cao and Zhang (2011) argue that information sharing is predominantly concerned with the quality and relevance of the information provided and hence is an intangible resource. Visibility, on the other hand is a broader capability whereby material, fund and information flows are captured, and renders the supply chain more transparent supply chain at a given time (Braunscheidel and Suresh, 2009). Transparency is important for building confidence among partners (Christopher and Lee, 2004) and leads to improved coordination and resource sharing (Maghsoudi and Pazirandeh, 2016) for better performance. In this paper, we consider upstream supply chain visibility in terms of connectivity and information sharing as a key capability to implement sustainability aspects in a supply chain. However, the broad empirical 
evidence for its effects still appear largely absent from the literature. To address this gap, we pose two questions. The first one is as follows: What are the effects of the information connectivity and information sharing on supply chain visibility?

We examine the conditions under which the supply chain visibility is effective in sustainable supply chains (Sousa and Voss, 2008; Boyd et al., 2012). We look into complexity, which has been increasingly recognized as one of the key area of managerial concern (see Choi and Krause, 2006; Eckstein et al. 2015; Perez Mesa and Gomez, 2015; Aitken et al. 2016) and a critical factor moderating various performance relationships (Jacob, 2013). In this context, we argue that complexity is one of the factors of uncertainty which may enhance or hamper the effectiveness of the supply chain visibility (Caridi et al. 2010 a). Caridi et al. (2010, 2010a) have attempted to explain how virtuality and complexity impact upon supply chain visibility using contingency theory. Building on Bozarth et al. (2009), we view supply chain complexity from the perspective of focal firm, and thus following the arguments of scholars (see Bozarth et al. 2009; Blome et al. 2013; Eckstein et al. 2015) we limit our focus on product complexity, which stems from the customization, intricacy, and the variety of the firm products. Product complexity is driven by number of factors including remanufacturing and product life-cycle (see Debo et al. 2005, 2006; Geyer et al. 2007); the latter is critical is critical for sustainable product development (Trotta, 2010) and sustainable supply chain design (Gupta and Palsule-Desai, 2011). However, research focusing on the effects of product complexity on sustainable supply chain design is still underdeveloped. Thus, our second research question is as follows: What are the effects of the product complexity on the relationship between supply chain visibility and social performancel environmental performanceleconomic performance? 
Our research is informed by contingency theory (Donaldson, 2001; Sousa and Voss, 2008; Bozarth et al. 2009; Boyd et al. 2012; Eckstein et al. 2015) and in particular contingent resource based view theory (CRBV) (Brush and Artz, 1999). Contingency theory and CRBV help us understand the contextual aspects and contingencies related to how and why organizations can implement sustainability aspects in the supply chains. Barney (1991), proposing the resource based view (RBV), focused on the role of resources and capabilities in assisting organizations achieve competitive advantage, while contingent RBV suggests that the completive advantage may be contingent on certain conditions. Brandon-Jones et al. (2014) have argued that specific conditions have a significant effect on the impact of resource bundling and capability building. Sirmon et al. (2007) argued in favor of a dynamic resource model to address environmental uncertainty; observed heterogeneity in the final outcome under similar initial conditions may be due to choices made related to structuring, bundling and leveraging of the resources. Therefore, based on the literature we argue that resources and capabilities which are possessed by the organization -in this case supply chain connectivity and supply chain information sharing (together referred to as "supply chain visibility")- may impact on supply chain sustainability performance (economic, social, and environmental) under the contingency of product complexity (Bozarth et al. 2009; Jacobs, 2013; Eckstein et al. 2015).

Our contribution to the operations and supply chain management literature is as follows. Firstly, building on Wu and Pagell (2011) and Lai et al. (2015) we investigate the impact of bundling resources to build supply chain visibility and its influence on supply chain sustainability performance. We argue that by building visibility in the supply chain, the sustainable supply chain performance can be improved significantly. We therefore address the endorsement of scholars to further investigate sustainability performance and visibility (Wu and Pagell, 2011). Secondly, we 
investigate the contingent role of product complexity in achieving sustainability performance through supply chain visibility. We argue that product complexity influences the impact of visibility on social performance, environmental performance and economic performance, extending thereby previous studies (e.g. Barratt and Oke, 2007; Holcomb et al. 2011; BrandonJones et al. 2014). Thirdly, we examine the contingency of product complexity based on the CRBV logic (Brush and Artz, 1999). We therefore extend earlier studies (e.g. Barratt and Oke, 2007; Holcomb et al. 2011; Brandon-Jones et al. 2014; Eckstein et al. 2015) by grounding our model in CRBV to explain this complex phenomenon. Finally, we add evidence and insights to the study of supply chain visibility and its influence on supply chain sustainability performance from the Indian context. In this vein we provide a better understanding of the sustainable supply chains in BRICs (Jabbour et al., 2012; Kannan et al., 2014; Gunasekaran et al., 2014; Dubey et al., 2015; Mani et al., 2016).

The remainder of the paper is structured as follows. Next, we introduce our theoretical model and research hypotheses. We then present our research design and methodology. Then follows our data analysis and the discussion of our results in light of the literature. Finally, we provide the limitations of our work and future research directions.

\section{Theoretical Framework and Hypotheses Development}

\subsection{Theoretical Framing}

This paper adopts the contingent RBV perspective (Brush and Artz, 1999). The RBV asserts that an organization can achieve competitive advantage by creating bundles based on the combination of resources and /or capabilities (Rumelt, 1984; Barney, 1991). Barratt and Oke (2007) argue that supply chain connectivity and information sharing have the potential to generate competitive advantage, if the resources or capabilities have the attributes of being valuable, rare, inimitable, 
and non-substitutable (Barney, 1991). Resources, per Barney (1991) can be broadly categorized as 'physical capital', 'human capital', and 'organizational capital'. Grant (1991) extends these resource types to include 'financial capital', 'technological capital', and 'reputational capital'. In a later study, Größler and Grübner (2006) argue that resources may be 'tangible', such as infrastructure, or 'intangible', such as information sharing. Bundling resources with specific practices and skill sets has also been highlighted as necessary for building capabilities (Sirmon et al., 2009).

The RBV has attracted significant attention from the operations and supply chain management community (Hitt et al. 2016). Brandon-Jones et al. (2014) argue, however, that still in the operations and supply chain management field there are limited studies discussing the bundling of capabilities and resources. Bundling resources and capabilities can have a significant impact on performance (see Zhu and Kraemer, 2002; Ravichandran and Lertwongsatien, 2005). Zhu and Kraemer (2002) suggest that bundling IT infrastructure (resources) and information sharing through e-commerce (capability) leads to improved performance. Ravichandran and Lertwongsatien (2005) further investigate how information systems (resources) and capabilities influence organizational performance. In a recent study, Golini et al. (2014) use RBV to discuss how capability building (i.e. site competence) can improve social and environmental performance in the supply chains.

Despite the popularity of RBV, critics suggest that RBV suffers from context insensitivity (Ling-Yee, 2007; Brandon-Jones et al. 2014). To address this criticism we follow Brush and Artz (1999) who propose the contingent RBV. Grotsch et al. (2013) argue that contingency theory can provide insights on how to utilize resources along with unique capabilities to achieve better outcomes in different situations. Eckstein et al. (2015) argue that contingency theory involves 
identifying and matching context settings with firm settings (Hambrick, 1983), whereas Donaldson (2001) notes that contingency theory assumes the nature of the firm's internal and external task environments. Hence, contingency theory argues that firms should adapt structures and processes to achieve desired fit with the environment to achieve better performance (Donaldson, 2001; Brandon-Jones et al. 2014; Eckstein et al. 2015). However, the contingent perspectives of RBV are underdeveloped in the literature (Brandon-Jones et al. 2014).

In this paper our focus is on sustainable supply chains where contingency theory addresses how internal and external conditions can guide those dealing with products within a sustainable supply chain network. Aragon-Correa and Sharma (2003) argue that contingent RBV may offer better insights by categorizing resources and capabilities of an organization based on certain internal and external contingencies. These, per Sirmon and Hitt (2009) may differentiate organizations in terms of the use of resources for the achievement of competitive advantage.

Zhu et al. (2008) argue that industry has three task environments: uncertainty, complexity and munificence, which have significant influence on managers' decisions. Pressure from stakeholders may force an organization to adopt proactive strategies such as environmental and social sustainability. Supply uncertainty, however, may not influence proactive strategies due to tendency of the organization to minimize the need due to scarce managerial resources (Carter and Roger, 2008), whereas less complexity may trigger proactive strategies such as environmental sustainability or social sustainability in comparison to more complex organizations. Hence, we consider product complexity as a contingency variable.

\subsection{Hypotheses Development}


We argue, following the CRBV perspective, that supply chain connectivity and information sharing can build capabilities which can further enhance sustainable supply chain performance under the contingent effects of firm size, product complexity, and time (see Figure 1). We see supply chain connectivity as mainly a technology issue. Furthermore, we define supply chain visibility as an organizational capability that enables supply chains to be more transparent in terms of demand and inventory levels. The supply chain visibility construct is visualized as a multidimensional second-order reflective construct of supply chain connectivity and information sharing, which in turn are conceptualized as first-order reflective constructs.

\subsubsection{Hierarchical Model specification}

Following Wetzels et al. (2009) arguments, our theoretical framework was specified as hierarchical model, representing the relationships between the indicators, sub-dimensions, and higher-order constructs. Hence, we have developed a three-order reflective model (see Figure 1).

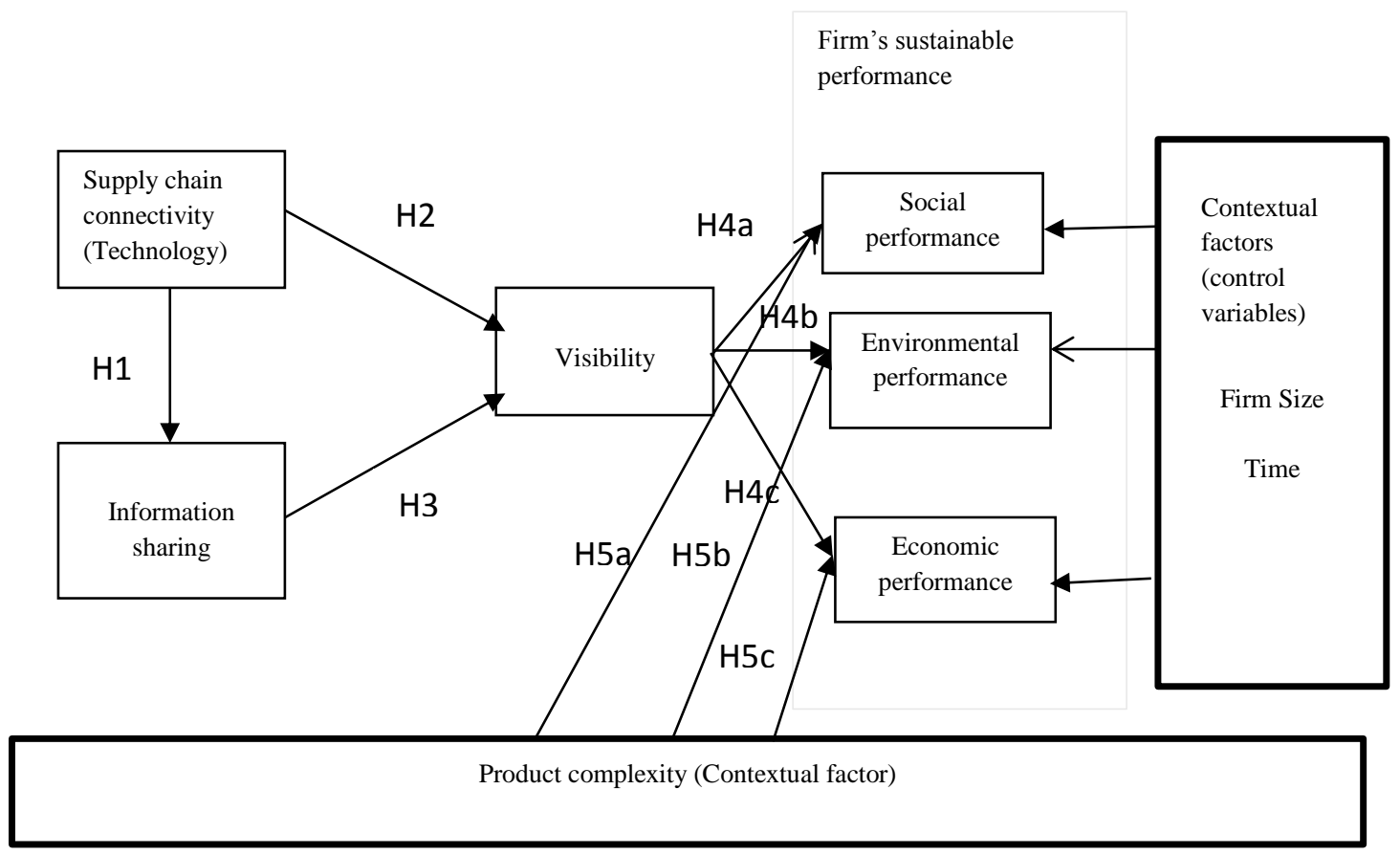




\section{Figure 1: Hypothesized Relationships}

\subsubsection{Hypotheses}

\subsubsection{Impacts of supply chain connectivity on information sharing}

Following RBV, resources are combined to create capabilities (Grant, 1991). We argue that supply chain connectivity and information sharing can be combined to create visibility in a supply chain network (see, Sirmon et al. 2007; Brandon-Jones et al. 2014). Premkumar and King (1994) argue that information sharing is an intangible resource that focuses on the flow of information. In a later study, Zhou and Benton (2007) argue that the value of the information sharing depends upon information quality. Brandon-Jones et al. (2014) note that information quality, accessibility, accuracy, and the relevance of the information depend upon the IT infrastructure. Hence, based on Cao and Zhang (2011) we argue that IT infrastructure is a tangible resource that plays a significant role in information sharing. Furthermore, following the literature (Zhu and Kraemer, 2002; Fawcett et al., 2007) IT infrastructure or support technology can be referred to as 'supply chain connectivity'. Fawcett et al. (2011) define supply chain connectivity as the ability of organizations to gather and share information using information and communication technologies (ICTs).

Hence, we can hypothesize:

H1: Upstream supply chain connectivity has a positive impact on information sharing.

\subsubsection{Impacts of supply chain connectivity on visibility}

We have already argued based on RBV that strategic resources and capabilities can generate competitive advantage (see Barney, 1991). Supply chain connectivity is an important resource for the development of capabilities within the supply chain (see Zhu and Kraemer, 2002; Wu et al. 2006; Brandon-Jones et al. 2014). Brandon-Jones et al. (2014) note that supply chain connectivity 
facilitates supply chain visibility. Hence based on RBV logic we conceptualize that supply chain connectivity and information sharing jointly form a capability, and we argue that supply chain connectivity is a prerequisite for building the capability of supply chain visibility. Therefore, we hypothesize:

H2: Upstream supply chain connectivity has a positive impact on upstream supply chain visibility.

\subsubsection{Impacts of information sharing on visibility}

Lee and Whang (2000) note that sharing of information related to inventory, sales, demand forecast, order status and production schedule using advanced information technology plays a significant role in the evolution of the supply chain. Christopher and Lee (2004) note that the sharing of appropriate and timely information among players in supply chains may improve visibility. In a later study, Brandon-Jones et al. (2014) argue that information sharing is an intangible resource, "while supply chain visibility is seen as a broader capability whereby material and information flows are captured" (p. 59). Barratt and Oke (2007) and Sezen (2008) study the relationship of information sharing to performance, arguing that information sharing leads to improved performance, whereas Barratt and Oke (2007) suggested that information sharing is an antecedent of supply chain visibility that leads to performance. Therefore,

H3: Information sharing has a positive impact on upstream supply chain visibility.

\subsubsection{Impacts of supply chain visibility on sustainable supply chain performance}

Francis (2008), in an extensive review of supply chain visibility, argue for its importance and relationship to supply chain performance while urging researchers to do further research on the term. Barratt and Oke (2007) further note that visibility in a supply chain has positive impacts on inventory level, product availability, flexibility, responsiveness and quality. Caridi et al. (2010) 
undertake extensive research on visibility and its impact on supply chain performance measures. They note that supply chain visibility impacts positively on total distribution costs, inventory level, service level, generic firm performance, delivery performance, product availability, flexibility, responsiveness and quality issues. Wu and Paggell (2011) discuss supply chain visibility as being vital to environmental decision making. However, so far researchers have not discussed the impact of visibility on social aspects and on the overall sustainable firm performance. Given that when referring to sustainability, the performance of a firm needs to be measured in terms of the triple bottom line (see Elkington 1999; Kleindorfer et al. 2005; Paggell and Wu, 2009; Wu and Pagell, 2011), that is, economic, social, and environmental aspects, we argue that supply chain visibility may have positive impacts on social performance, environmental performance and firm performance. Therefore:

H4a: Upstream supply chain visibility has a positive impact on social performance.

H4b: Upstream supply chain visibility has a positive impact on environmental performance.

H4c: Upstream supply chain visibility has a positive impact on economic performance.

\subsubsection{Moderating role of product complexity}

Jacobs (2013) argue that product complexity is a significant concern for managers and can undermine operational performance if not managed well; if managed well it could be used for gaining competitive advantage. Product complexity has received increasing attention from various scholars (see Bozarth et al. 2009; Jacobs, 2013; Eckstein et al. 2015; Caniato and Grobler, 2015), however the role of product complexity on firm sustainable performance is still underdeveloped. Eckstein et al. (2015) attempt to test the moderating effect of product complexity on the relationship between supply chain agility and adaptability on organizational performance. Even 
though there are mixed views in the literature regarding the role of product complexity (see Fisher et al. 1999; Closs et al. 2010), we argue that product complexity may moderate sustainable supply chain performance, and hence in our study we investigate the moderating role of product complexity on sustainable supply chain performance. Therefore,

H5a: Product complexity positively moderates the effect of upstream supply chain visibility on social performance;

H5b: Product complexity positively moderates the effect of upstream supply chain visibility on environmental performance;

H5c: Product complexity positively moderates the effect of upstream supply chain visibility on economic performance.

\section{Research Design}

\subsection{Construct Operationalization}

To test our research hypotheses, we use the survey method. A survey questionnaire was developed by identifying appropriate measures from our extensive literature review. The scales were pretested and modified using an expert panel comprising industry practitioners and academics. The five industry experts whom we selected had over fifteen years of experience in the supply chain management field and are members of APICS, ISM and CILT UK. The academics were selected based on their related research works published in the highly-ranked (ABS $4^{*}$ and $\mathrm{ABS} 3^{*}$ ) journals listed by the Financial Times and the Chartered Association of Business Schools (2015). The finalized questionnaire includes reflective constructs and their measures as discussed next and shown in Appendix 1. We have measured each item on a five-point Likert scale with anchors ranging from strongly disagree (1) to strongly agree (5). 


\section{Supply chain connectivity}

We measured supply chain connectivity using a scale developed by Fawcett et al. (2011) and further modified it using Brandon-Jones et al.'s (2014) scale. The three-item construct (see Appendix 1) examines the extent to which the use of ICTs facilitates quality information exchange in the supply chain.

\section{Information sharing}

We measured information sharing using Brandon-Jones et al. (2014) five measures scale, developed by Cao and Zhang (2011). The five-item construct (see Appendix 1) assess the extent of relevant, timely, accurate and complete information sharing occurring between suppliers, manufacturers, logistic service providers and dealers.

\section{Supply Chain Visibility}

We used Brandon-Jones et al.'s (2014) two-item construct, grounded in Braunscheidel and Suresh (2009). The two-item construct (see Appendix 1) examines the extent to which inventory and demand levels are visible throughout the supply chain.

\section{Product complexity}

We measure product complexity using Eckstein et al.'s (2015) three-item construct (see Appendix 1). The construct examines the extent to which product complexity is well managed to improve the sustainable supply chain performance.

\section{Social performance}

We used Hutchins and Sutherland's (2008) twelve-item construct (see Appendix 1). It examines the extent to which labor equity, health related issues, education, and housing security related issues are well addressed without compromising with quality, profit, and environment. 


\section{Environmental performance}

We used Zhu and Sarkis' (2004) six-item construct that examines the extent to which the negative consequences of supply chain activities on the environment are reduced (see Appendix 1).

\section{Economic performance}

We used Zhu and Sarkis' (2004) five-item construct (see Appendix 1) that examines the extent of reduced costs due to waste and injuries. We measured each item on a five point Likert scale with anchors ranging from strongly disagree (1) to strongly agree (5).

\section{Statistical Controls}

To fully account for the differences among organizations, we included firm size and time as control variables. To measure firm size, we used 'number of employees' and 'revenue' (Liang et al. 2007). Finally, we included 'time' since the adoption of sustainable practices in supply chains is a dynamic process and misalignments which might have existed initially due to poor coordination may have been resolved to a certain extent. Thus, this variable takes into account the learning effect (Liang et al. 2007).

\subsection{Data collection}

In this study the unit of analysis employed was at the level of manufacturing plant and its constituent upstream suppliers. Prior research has indicated that this analysis provided a detailed understanding of supply chain network design (see Brandon-Jones et al. 2014; c.f. Bozarth et al. 2009). We utilized a cross-sectional e-mail survey of a sample of Indian manufacturing companies

drawn from the Confederation of Indian Industries (CII) database and further validated using a database provided by Dun \& Bradstreet. Eighteen hundred respondents were selected from the CII database situated across India. The title of the respondents sought was primarily Vice President or 
Director of Supply Chain Management, Logistics Management, or Materials Management (see Table 1).

In an effort to increase the response rate we followed Dillman's tailored design test method with new internet and mixed mode guidelines (see Dillman, 2011). Survey questionnaires were emailed to the 1800 respondents. Each survey questionnaire included a cover letter in which the purpose of the study was explained. After two weeks, we had received 160 usable responses. We sent further reminders via e-mail and followed up by phone. After three weeks, we had received a further 152 usable responses. Hence, we received a total of 312 usable responses, which represents $17.33 \%(312 / 1800=17.33 \%)$. In comparison to similar studies in operations and supply chain management (see Braunscheidel and Suresh, 2009; Eckstein et al. 2015; Lai et al. 2015), our sample size is sufficient for a hypotheses test.

To test for non-response bias, we followed the steps by Armstrong and Overton (1977). We compared the responses of early and late waves of returned survey based on assumption that the opinions of the late respondents are representative of the opinions of the non-respondents (see Armstrong and Overton, 1977; Lambert and Harrington, 1990). However, Fawcett et al. (2014) noted that comparing early to late respondents may not be a strong test of nonresponse bias. Hence, we also adopted alternative techniques (see Fawcett et al. 2014) and compared the demographics of the late respondents via a Dun \& Bradstreet database and further followed up by making a phone call to increase the confidence level of the late respondents. The t-tests yielded no statistically significant differences between early-wave (160 responses) and late-wave (152 responses), suggesting that non-response bias was not a problem. 
The final sample consisted of 42 directors (13.46\%), 98 vice-presidents (31.41\%) and 172 general managers $(55.13 \%)$. The respondents primarily worked for medium to large firms with $30 \%$ of the respondents working for large firms with more than 1000 employees and a gross income of more than US \$150 million. The respondents are evenly distributed among the six NIC codes selected.

Table 1: Sample Profile ( $=312)$

\begin{tabular}{|l|r|r|}
\hline Industry Code(NIC) & Count & Percent \\
\hline 16 (Wood and products of wood) & 18 & 5.77 \\
\hline 17 (Manufacture of paper and paper products) & 23 & 7.37 \\
\hline 19 (Manufacture of coke and refined petroleum products) & 28 & 8.97 \\
\hline 20 (Manufacture of chemicals and chemical products) & 67 & 21.47 \\
\hline 22 (Manufacture of rubber and rubber products) & 82 & 26.28 \\
\hline $\begin{array}{l}\text { 25 (Manufacture of fabricated metal products, except machinery and } \\
\text { equipment) }\end{array}$ & 94 & 30.13 \\
\hline & & \\
\hline Number of employees & 48 & 15.38 \\
\hline Less than 100 & 70 & 22.44 \\
\hline $101-500$ & 100 & 32.05 \\
\hline $501-1000$ & 94 & 30.13 \\
\hline 1000 or more & & \\
\hline & & \\
\hline Annual Sales (US\$) & 93 & 29.81 \\
\hline 150 million and above & 150 & 48.08 \\
\hline more than 100 million and less than 150 million & 69 & 22.12 \\
\hline Less than 100 million & & \\
\hline & & \\
\hline Position of the respondents & 42 & 13.46 \\
\hline Directors & 98 & 31.41 \\
\hline Vice-Presidents & 55.13 \\
\hline General Managers & & \\
\hline
\end{tabular}

\section{Data Analysis and Results}

Before evaluating reliability and validity of the constructs and their measures, the indicators were tested for constant variance, existence of outliers, and normality. We used plots of residuals by 
predicted values and statistics of skewness and kurtosis. The maximum absolute values of skewness and kurtosis of the indicators in the remaining dataset were found to be 1.53 and 4.75 , respectively. These values were well within the limits recommended by Curran et al. (1996) which suggest skewness $<2$, kurtosis $<7$. Finally, neither the plots nor the statistics indicated any significant deviance from the assumptions.

\subsection{Measurement Model}

We used the co-variance based method (AMOS 19.0) for conducting data analysis. We conducted confirmatory factor analysis (CFA) to estimate the measurement properties of the multi-item constructs (see Figure 1). All factor loadings were more than the commonly accepted 0.5 standard of Hair et al. (2006). The model revealed a good fit to the data. Based on the recommendations of various researchers (see Bentler and Bonett, 1980; Hair et al. 2006; Hooper et al. 2008) we obtained the following fit indices: $\chi^{2} /$ degrees of freedom $=179$; goodness of fit $[\mathrm{GFI}]=0.98$; adjusted goodness of fit $[\mathrm{AGFI}]=0.96$; Bentler and Bonnet's normed fit index $[\mathrm{NFI}]=0.97$; Bentler comparative fit index $[\mathrm{CFI}]=0.99$; root mean square residual $[\mathrm{RMSR}]=0.04$; root mean square error of approximation $[\mathrm{RMSEA}]=0.05$. We further followed a series of procedures (see Fornell and Larcker, 1981; Hair et al. 2006; Li et al. 2016) to assess convergent and discriminant validity. In support of convergent validity, we observed that all the factor loadings were significant and greater than 0.5 ; scale composite reliability (SCR) greater than 0.7 and average variance extracted (AVE) greater than 0.5 (see Table 2). 
Table 2: Confirmatory Factor Analysis

\begin{tabular}{|c|c|c|c|c|c|c|}
\hline Constructs & Indicators & $\begin{array}{l}\text { Factor } \\
\text { Loadings }\end{array}$ & Variance & Error & SCR & AVE \\
\hline \multirow{3}{*}{$\begin{array}{l}\text { Supply Chain } \\
\text { Connectivity } \\
\text { (SCC) }\end{array}$} & $\begin{array}{l}\text { SC1 (current information } \\
\text { systems) }\end{array}$ & 0.74 & 0.54 & 0.46 & \multirow{3}{*}{0.82} & \multirow{3}{*}{0.60} \\
\hline & $\begin{array}{l}\text { SC2 (Information } \\
\text { applications) }\end{array}$ & 0.80 & 0.64 & 0.36 & & \\
\hline & $\begin{array}{l}\text { SC3 (adequate } \\
\text { information systems } \\
\text { linkage) }\end{array}$ & 0.78 & 0.60 & 0.40 & & \\
\hline \multirow{4}{*}{$\begin{array}{l}\text { Information } \\
\text { sharing } \\
\text { (IS) }\end{array}$} & IS1 (relevant information) & 0.59 & 0.35 & 0.65 & \multirow{4}{*}{0.91} & \multirow{4}{*}{0.71} \\
\hline & IS2 (timely information) & 0.88 & 0.77 & 0.23 & & \\
\hline & IS3 (accurate information) & 0.88 & 0.77 & 0.23 & & \\
\hline & $\begin{array}{l}\text { IS4 (confidential } \\
\text { information) }\end{array}$ & 0.97 & 0.95 & 0.05 & & \\
\hline \multirow{2}{*}{$\begin{array}{l}\text { Supply chain } \\
\text { visibility } \\
\text { (SCV) }\end{array}$} & SCV1 (Inventory levels) & 0.90 & 0.82 & 0.18 & \multirow[b]{2}{*}{0.90} & \multirow[b]{2}{*}{0.82} \\
\hline & SCV2 (demand levels) & 0.90 & 0.82 & 0.18 & & \\
\hline \multirow{3}{*}{$\begin{array}{l}\text { Product } \\
\text { complexity } \\
\text { (PC) }\end{array}$} & PC1 (diverse add-ons) & 0.91 & 0.83 & 0.17 & \multirow{3}{*}{0.95} & \multirow{3}{*}{0.87} \\
\hline & $\begin{array}{l}\text { PC2 (high number of } \\
\text { components) }\end{array}$ & 0.90 & 0.82 & 0.18 & & \\
\hline & $\begin{array}{l}\text { PC3 (new product } \\
\text { variants) }\end{array}$ & 0.98 & 0.96 & 0.04 & & \\
\hline \multirow{9}{*}{$\begin{array}{l}\text { Social } \\
\text { performance } \\
\quad \text { (SP) }\end{array}$} & SP1 (gender equality) & 0.69 & 0.47 & 0.53 & \multirow{9}{*}{0.93} & \multirow{9}{*}{0.59} \\
\hline & SP3 (poverty reduction) & 0.80 & 0.64 & 0.36 & & \\
\hline & SP4 (nutritional status) & 0.85 & 0.73 & 0.27 & & \\
\hline & SP5 (sanitation) & 0.81 & 0.66 & 0.34 & & \\
\hline & SP6 (safe drinking water) & 0.87 & 0.76 & 0.24 & & \\
\hline & SP7 (health care delivery) & 0.95 & 0.91 & 0.09 & & \\
\hline & SP9 (proper residence) & 0.56 & 0.31 & 0.69 & & \\
\hline & SP10 (transport facility) & 0.61 & 0.37 & 0.63 & & \\
\hline & SP11 (living conditions) & 0.69 & 0.48 & 0.52 & & \\
\hline \multirow{4}{*}{$\begin{array}{l}\text { Environmental } \\
\text { performance } \\
\text { (EP) }\end{array}$} & $\begin{array}{l}\text { EP1 (reduction of air } \\
\text { emission) }\end{array}$ & 0.87 & 0.76 & 0.24 & \multirow{4}{*}{0.92} & \multirow{4}{*}{0.67} \\
\hline & $\begin{array}{l}\text { EP2 (reduction of waste } \\
\text { water) }\end{array}$ & 0.68 & 0.46 & 0.54 & & \\
\hline & $\begin{array}{l}\text { EP3 (reduction of solid } \\
\text { waste) }\end{array}$ & 0.89 & 0.79 & 0.21 & & \\
\hline & $\begin{array}{l}\text { EP4 (reduction of } \\
\text { consumption for } \\
\text { hazardous harmful toxic } \\
\text { materials) }\end{array}$ & 0.85 & 0.73 & 0.27 & & \\
\hline
\end{tabular}




\begin{tabular}{|c|c|c|c|c|c|c|}
\hline & $\begin{array}{l}\text { EP5 (reduction of } \\
\text { frequency of } \\
\text { environmental accidents) }\end{array}$ & 0.81 & 0.65 & 0.35 & & \\
\hline & $\begin{array}{l}\text { EP6 (improve enterprises } \\
\text { environmental situations) }\end{array}$ & 0.79 & 0.63 & 0.37 & & \\
\hline \multirow{5}{*}{$\begin{array}{l}\text { Economic } \\
\text { performance } \\
(\mathrm{ECOP})\end{array}$} & $\begin{array}{l}\text { ECOP1 (decrease in } \\
\text { materials purchasing cost) }\end{array}$ & 0.94 & 0.87 & 0.13 & \multirow{5}{*}{0.97} & \multirow{5}{*}{0.88} \\
\hline & $\begin{array}{l}\text { ECOP2 (decrease of cost } \\
\text { for energy consumption) }\end{array}$ & 0.95 & 0.91 & 0.09 & & \\
\hline & $\begin{array}{l}\text { ECOP3 ( decrease in fee } \\
\text { for waste treatment) }\end{array}$ & 0.94 & 0.88 & 0.12 & & \\
\hline & $\begin{array}{l}\text { ECOP4 (decrease of fee } \\
\text { for waste discharge) }\end{array}$ & 0.93 & 0.87 & 0.13 & & \\
\hline & $\begin{array}{l}\text { ECOP5 (decrease of fine } \\
\text { for environmental } \\
\text { accidents) }\end{array}$ & 0.94 & 0.88 & 0.12 & & \\
\hline
\end{tabular}

Discriminant validity was next assessed, via both inter-correlations and AVE comparisons. The construct inter-correlations were between -1 and 1 , and all the squared inter-correlations were less than the AVE estimates for either construct in pairing, supporting discriminant validity (see Table 3).

Table 3: Inter-correlations of Constructs

\begin{tabular}{|c|c|c|c|c|c|c|c|}
\hline & SCC & IS & SCV & PC & SP & EP & ECOP \\
\hline SCC & $\mathbf{0 . 7 7 *}$ & & & & & & \\
\hline IS & 0.16 & $\mathbf{0 . 8 4} *$ & & & & & \\
\hline SCV & 0.20 & 0.50 & $\mathbf{0 . 9 1 *}$ & & & & \\
\hline PC & -0.19 & -0.05 & -0.12 & $\mathbf{0 . 9 3} *$ & & & \\
\hline SP & 0.22 & 0.33 & 0.40 & 0.04 & $\mathbf{0 . 7 7 *}$ & & \\
\hline EP & -0.05 & 0.22 & 0.09 & 0.27 & 0.04 & $\mathbf{0 . 8 2} *$ & \\
\hline ECOP & 0.36 & 0.05 & 0.13 & -0.18 & 0.00 & 0.03 & $\mathbf{0 . 9 4 *}$ \\
\hline
\end{tabular}

\footnotetext{
* square of AVE
} 


\subsection{Common Method Bias (CMB)}

Podsakoff et al. (2003) noted that in all self-reported data, there is a potential for common biases resulting from multiple sources such as consistency motif and social desirability. Following Podsakoff and Organ (1986), we requested our respondents not to estimate environmental performance and economic performance related questions purely based on memory. Instead we requested our respondents to get this information from documents maintained by the organizations. Secondly, we performed statistical analyses to assess the severity of common method bias by performing the Harmon one-factor test (Podsakoff and Organ, 1986; Liang et al. 2007) on seven constructs in our theoretical model (Figure 1). The result suggests that all the seven constructs are present and the maximum co-variance explained by one factor is 14.8 percent (see Appendix 2), indicating that $\mathrm{CMB}$ are not likely to impact upon our study.

\subsection{Hypothesis Testing}

We have tested our research hypotheses using multiple regression analysis (see Zailani et al. 2012) with hierarchical moderation tests applied as necessary based on prior studies (see Brandon-Jones et al. 2014; Eckstein et al. 2015; Dubey and Gunasekaran, 2015). We tested for multi-collinearity of the interaction terms (see Aiken and West, 1991; Chen and Paulraj, 2004; Eckstein et al. 2015). The multi-collinearity was tested by calculating variance inflation factors (VIF). The calculated values for each regression coefficient were from 1.00 to 3.45 , significantly lower than the recommended threshold of 10 (Hair et al. 2006).

Table 4 summarizes the results for hypotheses H1-H3. Addressing H1 we found that supply chain connectivity (SCC) is positively linked with information sharing (IS) $(\beta=0.787 ; \mathrm{t}=14.975)$. The result obtained is found to be consistent with prior studies (Barratt and Oke, 2007; Brandon-Jones et al. 2014). The control variable 'firm size' does not have a significant effect on the model ( $\beta=-$ 
0.064; $\mathrm{t}=-1.46)$. We therefore interpret the results that the supply chain connectivity helps significantly in information sharing. The size of the firm has very little to do in supply chain connectivity-information sharing relationship.

Addressing $\mathrm{H} 2$ and $\mathrm{H} 3$, we find that the results support both hypotheses (see Table 4). $\mathrm{H} 2$ ( $\beta=0.218$; $\mathrm{t}=2.965)$, indicates that supply chain connectivity (SCV) has a positive impact on upstream supply chain visibility and $\mathrm{H} 3(\beta=0.684 ; \mathrm{t}=10.064)$ indicates that information sharing (IS) has a positive impact on upstream supply chain visibility (SCV). Thus, our results are consistent with the findings of Brandon-Jones et al. (2014). The role of information sharing on supply chain visibility further support the results by Lai et al. (2015) in the context of Hong Kong firms. Based on the regression analyses (see Table 4), H1-H3 are supported. Hence, we can argue that resources (supply chain connectivity and information sharing) are important for creating visibility in a sustainable supply chain network.

Table 4: Supply Chain Visibility and Supply Chain Information Sharing Regression Results

\begin{tabular}{|c|c|c|c|c|}
\hline & \multicolumn{2}{|r|}{$\mathrm{DV}=\mathrm{IS}$} & \multicolumn{2}{|r|}{$\mathrm{DV}=\mathrm{SCV}$} \\
\hline Variables & $\beta$ & t-value & $\mathrm{B}$ & t-value \\
\hline \multicolumn{5}{|l|}{ Control } \\
\hline Firm size & -0.064 & -1.46 & -0.026 & -0.381 \\
\hline \multicolumn{5}{|c|}{ Main effects } \\
\hline $\mathrm{SCC}$ & 0.787 & 14.975 & 0.218 & 2.965 \\
\hline IS & & & 0.684 & 10.064 \\
\hline \multicolumn{5}{|c|}{ Model Summary } \\
\hline $\mathrm{R}^{2}$ & 0.528 & & 0.619 & \\
\hline Adj R ${ }^{2}$ & 0.523 & & 0.613 & \\
\hline Model F & 112.283 & & 108.312 & \\
\hline
\end{tabular}


$\mathrm{H} 4$ and its sub-hypotheses ( $\mathrm{H} 4 \mathrm{a}, \mathrm{H} 4 \mathrm{~b}$ and $\mathrm{H} 4 \mathrm{c})$ were tested using hierarchical moderated multiple regression. Specifically, three models, for social performance (SP), environmental performance (EP) and economic performance (ECOP) as dependent variables, were tested.

Addressing $\mathrm{H} 4 \mathrm{a}-\mathrm{H} 4 \mathrm{c}$, we find (see Table 5) that $\mathrm{H} 4 \mathrm{a}(\beta=0.387 ; \mathrm{t}=8.463)$ and $\mathrm{H} 4 \mathrm{~b}(\beta=0.258 ; \mathrm{t}=3.18)$ are supported. Our findings support the view of Wu and Pagell (2011) regarding the role of visibility in upstream supply chains. Our interpretation for the results is that extra effort to improve supply chain visibility may help to enhance social and environmental performance. However, the visibility seems to have no significant influence on the economic performance (H4c: $\beta=0.106$; $\mathrm{t}=1.312$ ). Surprisingly, this hypothesis was not supported which run contrary to many findings. This study support Holcomb et al. (2011) findings which noted mixed results in context to impact of visibility on firm performance. However, Holcomb et al. (2011) focused on the role of culture to differentiate between North American and European markets, whereas in our study we have not considered country culture or organizational culture. Furthermore, literature suggest that visibility in terms of inventory and demand may hinder coordination due to behavioral uncertainty (Kwon and Suh, 2004), and that trust and commitment play an important role in reducing opportunistic behavior (Morgan and Hunt, 1994). Nevertheless, no data on trust, commitment and behavioral uncertainty was collected in our survey. Finally, we also cannot ignore data related issues which may have influence on weak beta values. The current study utilizes cross-sectional data gathered using pre-tested instrument. Guide and Ketokivi (2015) in their recent editorial note have compiled some interesting observations which offers us to reflect upon weak beta values. The beta coefficient is found to be insignificant in our case which may be due to problem of endogeneity and CMB. Although we have undertaken necessary statistical tests to ensure that the endogeneity problem and $\mathrm{CMB}$ does not have major influence, we admit that the problem of endogeneity and 
CMB cannot be eliminated. The endogeneity problem may lead to asymptotic bias in parameter estimation (Guide and Ketokivi, 2015).

Next addressing H5a-H5c, we find (Table 5) product complexity (PC) has positive moderating effects on social performance $(\mathrm{SP})(\beta=0.012 ; \mathrm{t}=3.734)$, environmental performance $(\mathrm{EP})(\beta=0.718$; $t=14.79)$ and economic performance $(E C O P)(\beta=0.014 ; t=2.368)$. Our interpretation of this result is that the product complexity can become an effective moderator between SCV and sustainable supply chain performance. This result suggests that the effort of the firm to develop supply chain visibility capability is generally justified as it leads to improved performance, in both complex and simple product environments. Supply chain visibility is more effective under high product complexity than under low complexity and may help the firm to handle complex product environments, resulting into better social and environmental performance. This result is consistent with prior research findings (see Kekre and Srinivasan, 1990; Quelch and Kenny, 1994), implying trade-offs for managers between sales growth through added product complexity and enhanced operational efficiency through product rationalization. Trading-off between product complexity and operational efficiency may help to strike balance between social, environmental and economic benefits of the firm.

Table 5: Firm sustainable performance hierarchical moderated regression results

\begin{tabular}{|l|l|l|l|l|l|l|}
\hline & \multicolumn{2}{|c|}{ DV= SP } & \multicolumn{2}{c|}{ DV=EP } & \multicolumn{2}{c|}{ DV=ECOP } \\
\hline Variables & $\mathrm{B}$ & $\mathrm{t}$-value & $\beta$ & t-value & $\beta$ & t-value \\
\hline Control & & & & & & \\
\hline Firm size & 0.008 & 0.064 & 0.013 & 0.085 & 0.152 & 0.833 \\
\hline Main effects & & & & & & \\
\hline SCV & 0.387 & 8.463 & 0.258 & 3.18 & 0.106 & 1.312 \\
\hline PC & 0.086 & 0.392 & 0.045 & 0.336 & 0.109 & 1.634 \\
\hline Interaction effects & & & & & & \\
\hline
\end{tabular}




\begin{tabular}{|l|l|l|l|l|l|l|}
$\mathrm{SCV} * \mathrm{PC}$ & 0.012 & 3.734 & 0.718 & 14.79 & 0.014 & 2.368 \\
\hline Model Summary & & & & & & \\
\hline $\mathrm{R}^{2}$ & 0.315 & & 0.56 & & 0.024 & \\
\hline Adj $\mathrm{R}^{2}$ & 0.313 & & 0.552 & & 0.014 & \\
\hline Model F & 136.99 & & 63.411 & & 2.448 & \\
\hline
\end{tabular}

\section{Discussion}

\subsection{Theoretical Contributions}

Our study makes three contributions to the sustainable supply chain literature. Firstly, the paper investigates the interplay of resources on building supply chain visibility to achieve sustainability performance. Especially in developing countries, organizations are under constant pressure from government or regulatory bodies to design sustainable supply chains. The achievement of sustainability performance has been a major concern, often attributed to lack of visibility (Wu and Pagell, 2011) and complexity (Caridi et al., 2010a). Nevertheless, no matter if the role of strategic sources and capabilities on visibility is well discussed in the operations and supply chain management literature (see Barratt and Oke, 2014; Brandon-Jones et al. 2014), what is less understood is how supply chain visibility impacts on economic, social and environmental sustainability. To address this gap and based on prior studies (see Barratt and Oke, 2007; BrandonJones et al. 2014) we proposed a theoretical model that conceptualizes supply chain connectivity and information sharing as bundled resources that build supply chain visibility as a capability under the contingent effect of product complexity to explain sustainable performance (conceptualized as economic, social, and environmental performance). By examining the direct effect of bundling of resources (i.e. supply chain connectivity and information sharing) on supply chain visibility, we argue the bundling of resources (i.e. supply chain connectivity and information sharing) improves supply chain visibility (capability) and impacts positively on social and 
environmental performance. We therefore elaborate on the arguments by $\mathrm{Wu}$ and Pagell (2011) and Lai et al. (2015) to further investigate the role of supply chain visibility in sustainable supply chains.

Secondly, it is not well understood the role of contingencies and product complexity in achieving sustainability performance through supply chain visibility. In the past scholars, have attempted to study the impact of product complexity on the relationship between internal and external knowledge transfers and supply chain flexibility and role of product complexity on supply chain agility and supply chain adaptability. However, to our best of the knowledge, the role of product complexity on supply chain visibility and sustainability performance is still less understood. To address this gap, we examine the moderating effect of product complexity on the influence of supply chain visibility on environmental performance, economic performance and social performance. We argue based on existing literature that product complexity can influence the impact of the visibility on social performance, environmental performance and economic performance. We therefore extend some earlier studies (e.g. Barratt and Oke, 2007; Holcomb et al. 2011; Brandon-Jones et al. 2014); by investigating product complexity as a contingent variable we offer an interesting insight to our understanding related to supply chain visibility.

We investigate the contingency of product complexity in achieving sustainability performance using the CRBV logic (Brush and Artz, 1999) that revolves around the bundling of strategic resources and /or capabilities (Barney, 1991) to generate competitive advantage under contingencies. We therefore extend earlier studies (e.g. Barratt and Oke, 2007; Holcomb et al. 2011; Brandon-Jones et al. 2014) and Eckstein et al. (2015) study on moderating effect of product complexity on supply chain designs, focusing on visibility and sustainability performance, and we ground our model in CRBV to explain this complex phenomenon. We believe product complexity 
as a contingent variable offers an interesting insight which further our understanding related to supply chain visibility and sustainability performance.

Finally, we contribute to the study of supply chain visibility and its influence on supply chain sustainability performance in the Indian context. We provide a better understanding of the sustainable supply chains in BRICs (Jabbour et al., 2012; Kannan et al., 2014; Gunasekaran et al., 2014; Dubey et al., 2015; Mani et al., 2016).

\subsection{Managerial Implications}

This study offers several useful implications for supply chain managers. Firstly, our study demonstrates that investments in supply chain visibility capabilities may generate different results depending on contingent factors. For organizations operating within complex environment (for examples, one having huge product variants), the social and environmental benefits increase with investments in supply chain visibility capability. Our results further assist managers who face a constant trade-off between profit, responsibility towards society and environmental related decisions. It has been noted in prior research that an increase in product lines may boost sales' growth due to increased customer satisfaction. However, this may lead to increase in obsolete inventory due to decrease in product life cycle and increase in globalization. In most cases organizations fail to strike a balance between sales and commitment towards society and environment. Hence, our study results indicate that exploitation of product complexity may help reduce negative effects of supply chain on environment, improve the living standard of the employees, and create better living conditions and improve profit margin. However, an important point to be noted is that the benefits are comparatively slower, and thus in the long term the proper management of product complexity may be good for supply chain sustainability. Our suggestions 
are based on data which we gathered using a pre-tested questionnaire. Presumably, it is in the best interest for companies to exploit connectivity and information sharing to generate supply chain visibility to achieve sustainable performance. Therefore, supply chain visibility under moderation effect of product complexity may help organization to achieve their sustainability goals.

\subsection{Limitations and future research directions}

Our research has the following limitations. Firstly, following the arguments by Ketokivi and Guide (2015), we argue that CMB may be an issue influencing our results. However, though following Podsakoff et al. (2003), we performed their suggested statistical test to minimize the influence of CMB but it should be noted that the CMB cannot be eliminated. Thus, to address CMB beside Harman's single-factor test, the data should be gathered from multiple-informants from single unit.

Secondly, the use of survey data may limit the scope of research (Markman and Krause, 2014) and therefore we propose the use of alternative methods, including, for instance, the use of qualitative methods in conjunction with quantitative methods (see Eisenhardt, 1989; Beach et al. 2001; Pagell and Wu, 2009; Barratt and Choi, 2011; Childe, 2011) to address some those questions which may not be answered using a single method (Boyer and Swink, 2008; Tang et al. 2016).

Thirdly, our theorizing is heavily driven by the contingent resource based view/theory. We believe the current study can be extended using the natural resource based view (Hart, 1995) to examine sustainable supply chain performance. Further studies could also aim at understanding the pressures behind the managerial decisions on information sharing and connectivity, visibility, and performance, and to this extend institutional theory could be used (Kauppi, 2013). Oliver (1997) argued that resource-based view has not looked beyond the properties and resource markets to explain enduring firm heterogeneity. It has not examined the social context within which resource 
selection decisions are embedded (e.g., firm traditions, network ties, regulatory pressures) and how this context might affect sustainable firm differences. Hence in this context integrating institutional theory with CRBV may help to understand how regulatory pressures can influence resource selection decision.

Finally, we have noted based on Holcomb et al. (2011) arguments that country culture or organizational culture may have an important role to play on degree of effectiveness of supply chain visibility and performance. Hence, it may be interesting to investigate in the future the role of organizational culture on supply chain visibility and its influence on sustainable performance measures. Furthermore, the role of opportunistic behavior may be influencing supply chain visibility and could be empirically examined in the future.

\section{Conclusion}

The current focused on the impact of product complexity on supply chain visibility and sustainability performance. We grounded our theoretical framework in CRBV to explain how bundling resources and capability under the contingent effect of product complexity can influence sustainable performance. We tested our research hypotheses and its sub-hypotheses using data gathered from 312 Indian organizations.

We found that supply chain visibility has a positive direct impact on environmental and social performance. Furthermore, we noted that under the moderating effect of the product-complexity supply chain visibility has a positive impact on environmental, social and economic performance. However, the weak beta values suggest that further research should utilise longitudinal data. However, as we realise that gathering longitudinal data is highly challenging. Hence, we cannot ignore the importance of survey based research but to ensure that endogeneity and CMB should 
not contaminate the results, the researchers need to further tighten their research design as per recent debates.

Similarly, our results on the moderation effect of product complexity further suggest that product complexity is still one of the major concerns within Indian organizations which is no doubt reflected in companies across the globe. Hence it is recommended that product complexity should be exploited to achieve better result of supply chain visibility on sustainable performance. We believe that we have provided food for thought to those researchers and practitioners who would like to study further the role of supply chain visibility in supply chain sustainability performance.

\section{References}

Aiken, L. S., West, S. G., \& Reno, R. R. (1991). Multiple regression: Testing and interpreting interactions. Sage.

Aitken, J., Bozarth, C., \& Garn, W. (2016). To eliminate or absorb supply chain complexity: A conceptual model and case study. Supply Chain Management: an International Journal, 21(6), 759-774.

Akhavan, R. M., \& Beckmann, M. (2017). A configuration of sustainable sourcing and supply management strategies. Journal of Purchasing and Supply Management, 23(2), 137-151.

Aragon-Correa, J. A., \& Sharma, S. (2003). A contingent resource-based view of proactive corporate environmental strategy. Academy of Management Review, 28(1), 71-88.

Armstrong, J. S., \& Overton, T. S. (1977). Estimating nonresponse bias in mail surveys. Journal of Marketing Research, 14(3), 396-402.

Arshinder, K.,Kanda, A., \& Deshmukh, S. G. (2008). Supply chain coordination: perspectives, empirical studies and research directions. International Journal of Production Economics, $115(2), 316-335$. 
Barratt, M., Choi, T. Y., \& Li, M. (2011). Qualitative case studies in operations management: Trends, research outcomes, and future research implications. Journal of Operations Management, 29(4), 329-342.

Barratt, M., \& Oke, A. (2007). Antecedents of supply chain visibility in retail supply chains: a resource-based theory perspective. Journal of Operations Management, 25(6), 1217-1233.

Barney, J. (1991). Firm resources and sustained competitive advantage. Journal of Management, 17(1), 99-120.

Beach, R., Muhlemann, A. P., Price, D. H. R., Paterson, A., \& Sharp, J. A. (2001). The role of qualitative methods in production management research. International Journal of Production Economics, 74(1), 201-212.

Bentler, P. M., \& Bonett, D. G. (1980). Significance tests and goodness of fit in the analysis of covariance structures. Psychological Bulletin, 88(3), 588-606.

Blome, C., Schoenherr, T., \& Rexhausen, D. (2013). Antecedents and enablers of supply chain agility and its effect on performance: a dynamic capabilities perspective. International Journal of Production Research, 51(4), 1295-1318.

Blome, C., Schoenherr, T., \& Eckstein, D. (2014). The impact of knowledge transfer and complexity on supply chain flexibility: A knowledge-based view. International Journal of Production Economics, 147, 307-316.

Bode, C., Wagner, S. M., Petersen, K. J., \& Ellram, L. M. (2011). Understanding responses to supply chain disruptions: Insights from information processing and resource dependence perspectives. Academy of Management Journal, 54(4), 833-856.

Boudon, R. (1991). What Middle-Range Theories Are. Contemporary Sociology, 20(4), 519-522. Retrieved from http://www.jstor.org/stable/2071781. 
Boyd, B. K., Haynes, K. T., Hitt, M. A., Bergh, D. D., \& Ketchen, D. J. (2012). Contingency Hypotheses in Strategic Management Research Use, Disuse, or Misuse?. Journal of Management, 38(1), 278-313.

Boyer, K. K., \& Swink, M. L. (2008). Empirical elephants-why multiple methods are essential to quality research in operations and supply chain management. Journal of Operations Management, 26(3), 338-344.

Bozarth, C. C., Warsing, D. P., Flynn, B. B., \& Flynn, E. J. (2009). The impact of supply chain complexity on manufacturing plant performance. Journal of Operations Management, 27(1), 78-93.

Brandenburg, M., \& Rebs, T. (2015). Sustainable supply chain management: a modeling perspective. Annals of Operations Research, 229(1), 213-252.

Brandon-Jones, E., Squire, B., Autry, C. W., \& Petersen, K. J. (2014). A Contingent ResourceBased Perspective of Supply Chain Resilience and Robustness. Journal of Supply Chain Management, 50(3), 55-73.

Braunscheidel, M. J., \& Suresh, N. C. (2009). The organizational antecedents of a firm's supply chain agility for risk mitigation and response. Journal of Operations Management, 27(2), 119-140.

Brush, T. H., \& Artz, K. W. (1999). Toward a contingent resource-based theory: The impact of information asymmetry on the value of capabilities in veterinary medicine. Strategic Management Journal, 20(3), 223-250.

Cao, M., \& Zhang, Q. (2011). Supply chain collaboration: Impact on collaborative advantage and firm performance. Journal of Operations Management, 29(3), 163-180. 
Caniato, F., \& Größler, A. (2015). The moderating effect of product complexity on new product development and supply chain management integration. Production Planning \& Control, 26(16), 1306-1317.

Carter, C. R., \& Rogers, D. S. (2008). A framework of sustainable supply chain management: moving toward new theory. International Journal of Physical Distribution \& Logistics Management, 38(5), 360-387.

Caridi, M., Crippa, L., Perego, A., Sianesi, A., \& Tumino, A. (2010). Measuring visibility to improve supply chain performance: a quantitative approach. Benchmarking: An International Journal, 17(4), 593-615.

Caridi, M., Crippa, L., Perego, A., Sianesi, A., \& Tumino, A. (2010a). Do virtuality and complexity affect supply chain visibility? International Journal of Production Economics, 127(2), 372-383.

Chen, I. J., \& Paulraj, A. (2004). Towards a theory of supply chain management: the constructs and measurements. Journal of Operations Management, 22(2), 119-150.

Chen, I. J., Paulraj, A., \& Lado, A. A. (2004a). Strategic purchasing, supply management, and firm performance. Journal of Operations Management, 22(5), 505-523.

Childe, S. J. (2011). Case studies in operations management. Production Planning \& Control, 22(2), 107.

Choi, T. Y., \& Krause, D. R. (2006). The supply base and its complexity: Implications for transaction costs, risks, responsiveness, and innovation. Journal of Operations Management, 24(5), 637-652.

Christopher, M. (2000). The agile supply chain: competing in volatile markets. Industrial Marketing Management, 29(1), 37-44. 
Christopher, M., \& Lee, H. (2004). Mitigating supply chain risk through improved confidence. International Journal of Physical Distribution \& Logistics Management, 34(5), 388-396.

Closs, D. J., Nyaga, G. N., \& Voss, M. D. (2010). The differential impact of product complexity, inventory level, and configuration capacity on unit and order fill rate performance. Journal of Operations Management, 28(1), 47-57.

Debo, L. G., Toktay, L. B., \& Van Wassenhove, L. N. (2005). Market segmentation and product technology selection for remanufacturable products. Management Science, 51(8), 11931205.

Debo, L. G., Toktay, L. B., \& Van Wassenhove, L. N. (2006). Joint Life-Cycle Dynamics of New and Remanufactured Products. Production and Operations Management, 15(4), 498-513.

Dillman, D. A. (2011). Mail and internet surveys: The tailored design method - 2007 update with new internet, visual, and mixed-mode guide. John Wiley \& Sons.

Donaldson, L. (2001). The Contingency Theory of Organizations. Sage Publications, Thousand Oaks.

Dubey, R., \& Gunasekaran, A. (2015). Exploring soft TQM dimensions and their impact on firm performance: Some exploratory empirical results. International Journal of Production Research, 53(2), 371-382.

Dubey, R., Gunasekaran, A., \& Ali, S. (2015). Exploring the relationship between leadership, operational practices, institutional pressures and environmental performance: A framework for green supply chain. International Journal of Production Economics 160, 120-132.

Eckstein, D., Goellner, M., Blome, C., \& Henke, M. (2015). The performance impact of supply chain agility and supply chain adaptability: the moderating effect of product complexity. International Journal of Production Research, 53(10), 3028-3046. 
Elkington, J. (1999). Triple bottom-line reporting. Looking for balance. Australian CPA, 18-21.

Eisenhardt, K. M. (1989). Building theories from case study research. Academy of Management Review, 14(4), 532-550.

Fahimnia, B., Sarkis, J., Gunasekaran, A., \& Farahani, R. (2017). Decision models for sustainable supply chain design and management. Annals of Operations Research, 250(2), 277-278.

Fawcett, S. E., Waller, M. A., Miller, J. W., Schwieterman, M. A., Hazen, B. T., \& Overstreet, R. E. (2014). A trail guide to publishing success: tips on writing influential conceptual, qualitative, and survey research. Journal of Business Logistics, 35(1), 1-16.

Fawcett, S. E., Osterhaus, P., Magnan, G. M., Brau, J. C., \& McCarter, M. W. (2007). Information sharing and supply chain performance: the role of connectivity and willingness. Supply Chain Management: an International Journal, 12(5), 358-368.

Fawcett, S. E., Wallin, C., Allred, C., Fawcett, A. M., \& Magnan, G. M. (2011). Information technology as an enabler of supply chain collaboration: a dynamic-capabilities perspective. Journal of Supply Chain Management, 47(1), 38-59.

Fisher, M., Ramdas, K., \& Ulrich, K. (1999). Component sharing in the management of product variety: A study of automotive braking systems. Management Science, 45(3), 297-315.

Fornell, C., \& Larcker, D. F. (1981). Evaluating structural equation models with unobservable variables and measurement error. Journal of Marketing Research, 18(1), 39-50.

Francis, V. (2008). Supply chain visibility: Lost in translation? Supply Chain Management: An International Journal, 13(3), 180-184.

Fredericks, E. (2005). Infusing flexibility into business-to-business firms: A contingency theory and resource-based view perspective and practical implications. Industrial Marketing Management, 34(6), 555-565. 
Geyer, R., Van Wassenhove, L. N., \& Atasu, A. (2007). The economics of remanufacturing under limited component durability and finite product life cycles. Management Science, 53(1), 88-100.

Golini, R., Longoni, A., \& Cagliano, R. (2014). Developing sustainability in global manufacturing networks: The role of site competence on sustainability performance. International Journal of Production Economics, 147, 448-459.

Grant, R. M. (1991). The resource-based theory of competitive advantage: implications for strategy formulation. California Management Review, 33(3), 114-135.

Größler, A., \& Grübner, A. (2006). An empirical model of the relationships between manufacturing capabilities. International Journal of Operations \& Production Management, 26(5), 458-485.

Grötsch, V. M., Blome, C., \& Schleper, M. C. (2013). Antecedents of proactive supply chain risk management-a contingency theory perspective. International Journal of Production Research, 51(10), 2842-2867.

Guide, V. D. R., \& Ketokivi, M. (2015). Notes from the Editors: Redefining some methodological criteria for the journal. Journal of Operations Management, (37), v-viii.

Gunasekaran, A., Jabbour, C.J.C., \& Jabbour, A.B.L.S. (2014). Managing organizations for sustainable development in emerging countries: an introduction. International Journal of Sustainable Development \& World Economy 21 (3), 195-197.

Gupta, S., \& Palsule-Desai, O. D. (2011). Sustainable supply chain management: review and research opportunities. IIMB Management Review, 23(4), 234-245.

Hair, J. F., Black, W. C., Babin, B. J., Anderson, R. E., \& Tatham, R. L. (2006). Multivariate Data Analysis (Vol. 6). Upper Saddle River, NJ: Pearson Prentice Hall. 
Hall, J., \& Matos, S. (2010). Incorporating impoverished communities in sustainable supply chains. International Journal of Physical Distribution \& Logistics Management, 40(1/2), 124-147.

Hambrick, D. C. (1983). High profit strategies in mature capital goods industries: A contingency approach. Academy of Management Journal, 26(4), 687-707.

Hart, S. L. (1995). A natural-resource-based view of the firm. Academy of Management Review, 20(4), 986-1014.

Hitt, M. A., Xu, K., \& Carnes, C. M. (2016). Resource based theory in operations management research. Journal of Operations Management, 41, 77-94.

Hobday, M. (1998). Product complexity, innovation and industrial organisation. Research Policy, 26(6), 689-710.

Holcomb, M. C., Ponomarov, S. Y., \& Manrodt, K. B. (2011, January). The relationship of supply chain visibility to firm performance. Supply Chain Forum: an International Journal, 12(2), $32-45$.

Hooper, D., Coughlan, J. \& Mullen, M. R. (2008). Structural Equation Modelling: Guidelines for Determining Model Fit. The Electronic Journal of Business Research Methods 6(1), 53 60.

Hutchins, M. J., \& Sutherland, J. W. (2008). An exploration of measures of social sustainability and their application to supply chain decisions. Journal of Cleaner Production, 16(15), 1688-1698.

Jabbour, C. J. C., Neto, A. S., Gobbo, J. A., Jr., Ribeiro, M. D. S., \& De Sousa Jabbour, A. B. L. (2015). Eco-innovations in more sustainable supply chains for a low-carbon economy: A multiple case study of human critical success factors in brazilian leading companies. International Journal of Production Economics, 164, 245-257. 
Jabbour, C. J. C., Da Silva, E. M., Paiva, E. L., \& Santos, F. C. A. (2012). Environmental management in Brazil: is it a completely competitive priority?. Journal of Cleaner Production, 21(1), 11-22.

Jacobs, M. A. (2013). Complexity: Toward an empirical measure. Technovation, 33(4), 111-118.

Kannan, D., de Sousa Jabbour, A. B. L., \& Jabbour, C. J. C. (2014). Selecting green suppliers based on GSCM practices: Using fuzzy TOPSIS applied to a Brazilian electronics company. European Journal of Operational Research, 233(2), 432-447.

Kauppi, K. (2013). Extending the use of institutional theory in operations and supply chain management research: Review and research suggestions. International Journal of Operations \& Production Management, 33(10), 1318-1345.

Kaur, H., \& Singh, S. P. (2016). Sustainable procurement and logistics for disaster resilient supply chain. Annals of Operations Research, 1-46.

Kekre, S., \& Srinivasan, K. (1990). Broader product line: a necessity to achieve success?. Management Science, 36(10), 1216-1232.

Khan, M., Hussain, M., \& Saber, H. M. (2016). Information sharing in a sustainable supply chain. International Journal of Production Economics. doi:10.1016/j.ijpe.2016.04.010.

Kleindorfer, P. R., Singhal, K., \& Wassenhove, L. N. (2005). Sustainable operations management. Production \& Operations Management 14(4), 482-492.

Kumar, D., Rahman, Z., \& Chan, F. T. (2016). A fuzzy AHP and fuzzy multi-objective linear programming model for order allocation in a sustainable supply chain: A case study. International Journal of Computer Integrated Manufacturing, 1-17. 
Kuo, T. C., Hsu, C. W., Huang, S. H., \& Gong, D. C. (2014). Data sharing: a collaborative model for a green textile/clothing supply chain. International Journal of Computer Integrated Manufacturing, 27(3), 266-280.

Kwon, I. W. G., \& Suh, T. (2004). Factors affecting the level of trust and commitment in supply chain relationships. Journal of Supply Chain Management, 40(1), 4-14.

Lai, K. H., Wong, C. W., \& Lam, J. S. L. (2015). Sharing environmental management information with supply chain partners and the performance contingencies on environmental munificence. International Journal of Production Economics, 164, 445-453.

Lambert, D. M., \& Harrington, T. C. (1990). Measuring nonresponse bias in customer service mail surveys. Journal of Business Logistics, 11(2), 5-25.

Lee, H. L., \& Whang, S. (2000). Information sharing in a supply chain. International Journal of Manufacturing Technology and Management, 1(1), 79-93.

Lee, H. L., So, K. C., \& Tang, C. S. (2000). The value of information sharing in a two-level supply chain. Management Science, 46(5), 626-643.

Lehoux, N., D’Amours, S., \& Langevin, A. (2014). Inter-firm collaborations and supply chain coordination: review of key elements and case study. Production Planning \& Control, 25(10), 858-872.

Li, G., Liu, W., Wang, Z., \& Liu, M. (2016). An empirical examination of energy consumption, behavioral intention, and situational factors: evidence from Beijing. Annals of Operations Research, 1-18.

Liang, H., Saraf, N., Hu, Q., \& Xue, Y. (2007). Assimilation of enterprise systems: the effect of institutional pressures and the mediating role of top management. MIS Quarterly, 31(1), 59-87. 
Ling-Yee, L. (2007). Marketing resources and performance of exhibitor firms in trade shows: A contingent resource perspective. Industrial Marketing Management, 36(3), 360-370.

Mabert, V. A., \& Venkataramanan, M. A. (1998). Special research focus on supply chain linkages: challenges for design and management in the 21st century. Decision Sciences, 29(3), 537552.

Maghsoudi, A., \& Pazirandeh, A. (2016). Visibility, resource sharing and performance in supply chain relationships: insights from humanitarian practitioners. Supply Chain Management: an International Journal, 21(1), 125-139.

Mani, V., Gunasekaran, A., Papadopoulos, T., Hazen, B., \& Dubey, R. (2016). Supply chain social sustainability for developing nations: Evidence from India. Resources, Conservation, \& Recycling 111, 42-52.

Markman, G., \& Krause, D. (2014). Special topic forum on theory building surrounding sustainable supply chain management. Journal of Supply Chain Management, 50(2), i-ii.

Marshall, D., McCarthy, L., Heavey, C., \& McGrath, P. (2015). Environmental and social supply chain management sustainability practices: construct development and measurement. Production Planning \& Control, 26(8), 673-690.

Morgan, R. M., \& Hunt, S. D. (1994). The commitment-trust theory of relationship marketing. The Journal of Marketing, 58(3),20-38.

Novak, S., \& Eppinger, S. D. (2001). Sourcing by design: Product complexity and the supply chain. Management science, 47(1), 189-204.

Oliver, C. (1997). Sustainable competitive advantage: Combining institutional and resource-based views. Strategic Management Journal, 18(9), 697-713. 
Pagell, M., \& Wu, Z. (2009). Building a more complete theory of sustainable supply chain management using case studies of 10 exemplars. Journal of supply chain management, 45(2), 37-56.

Pérez Mesa, J. C., \& Gómez, E. G. (2015). Collaborative firms managing perishable products in a complex supply network: An empirical analysis of performance. Supply Chain Management: an International Journal, 20(2), 128-138.

Podsakoff, P. M., MacKenzie, S. B., Lee, J. Y., \& Podsakoff, N. P. (2003). Common method biases in behavioral research: a critical review of the literature and recommended remedies. Journal of Applied Psychology, 88(5), 879-903.

Podsakoff, P. M., \& Organ, D. W. (1986). Self-reports in organizational research: Problems and prospects. Journal of Management, 12(4), 531-544.

Premkumar, G., \& King, W. R. (1994). Organizational characteristics and information systems planning: An empirical study. Information Systems Research, 5(2), 75-109.

Pullman, M. E., Maloni, M. J., \& Carter, C. R. (2009). Food for thought: social versus environmental sustainability practices and performance outcomes. Journal of Supply Chain Management, 45(4), 38-54.

Quelch, J. A., \& Kenny, D. (1994). Extend profits, not product lines. Make Sure All Your Products Are Profitable, Harvard Business Review, 72(5), 153-160.

Ravichandran, T., Lertwongsatien, C. (2005). Effect of information systems resources and capabilities on firm performance: A resource-based perspective. Journal of Management Information Systems, 21(4), 237-276.

Rumelt, R. P. (1984). 'Towards a strategic theory of the firm'. In: R. Lamb (Ed.) Competitive Strategic Management. Prentice-Hall, Englewood Cliffs, NJ, 556-570. 
Sezen, B. (2008). Relative effects of design, integration and information sharing on supply chain performance. Supply Chain Management: an International Journal, 13(3), 233-240.

Sarkis, J., Zhu, Q., \& Lai, K. H. (2011). An organizational theoretic review of green supply chain management literature. International Journal of Production Economics, 130(1), 1-15.

Sirmon, D. G., Hitt, M. A., \& Ireland, R. D. (2007). Managing firm resources in dynamic environments to create value: Looking inside the black box. Academy of Management Review, 32(1), 273-292.

Sirmon, D. G., \& Hitt, M. A. (2009). Contingencies within dynamic managerial capabilities: interdependent effects of resource investment and deployment on firm performance. Strategic Management Journal, 30(13), 1375-1394.

Song, M. L., Fisher, R., Wang, J. L., \& Cui, L. B. (2016). Environmental performance evaluation with big data: Theories and methods. Annals of Operations Research, 1-14.

Sousa, R., \& Voss, C. A. (2008). Contingency research in operations management practices. Journal of Operations Management, 26(6), 697-713.

Tang, A. K., Lai, K. H., \& Cheng, T. C. E. (2016). A Multi-research-method approach to studying environmental sustainability in retail operations. International Journal of Production Economics, 171, 394-404.

Trotta, M. G. (2010). Product Lifecycle Management: Sustainability and knowledge management as keys in a complex system of product development. Journal of Industrial Engineering and Management, 3(2), 309-322.

Wei, H. L., \& Wang, E. T. (2010). The strategic value of supply chain visibility: increasing the ability to reconfigure. European Journal of Information Systems, 19(2), 238-249. 
Wetzels, M., Odekerken-Schröder, G., \& Van Oppen, C. (2009). Using PLS path modeling for assessing hierarchical construct models: Guidelines and empirical illustration. MIS Quarterly, 177-195.

Wu, F., Yeniyurt, S., Kim, D., \& Cavusgil, S. T. (2006). The impact of information technology on supply chain capabilities and firm performance: A resource-based view. Industrial Marketing Management, 35(4), 493-504.

Wu, Z., \& Pagell, M. (2011). Balancing priorities: Decision-making in sustainable supply chain management. Journal of Operations Management, 29(6), 577-590.

Zailani, S., Jeyaraman, K., Vengadasan, G., \& Premkumar, R. (2012). Sustainable supply chain management (SSCM) in Malaysia: A survey. International Journal of Production Economics, 140(1), 330-340.

Zhang, A. N., Goh, M., \& Meng, F. (2011). Conceptual modelling for supply chain inventory visibility. International Journal of Production Economics, 133(2), 578-585.

Zhu, K., \& Kraemer, K. L. (2002). E-commerce metrics for net-enhanced organizations: Assessing the value of e-commerce to firm performance in the manufacturing sector. Information Systems Research, 13(3), 275-295.

Zhu, Q., \& Sarkis, J. (2004). Relationships between operational practices and performance among early adopters of green supply chain management practices in Chinese manufacturing enterprises. Journal of Operations Management, 22(3), 265-289.

Zhu, Q., Sarkis, J., \& Lai, K. H. (2008). Green supply chain management implications for “closing the loop". Transportation Research Part E: Logistics and Transportation Review, 44(1), 1-18. 
Appendix 1:

\begin{tabular}{|c|c|c|}
\hline Constructs & $\begin{array}{l}\text { Indicator } \\
\mathrm{S}\end{array}$ & Items \\
\hline \multirow{3}{*}{$\begin{array}{l}\text { Supply Chain } \\
\text { Connectivity } \\
\text { (SCC) }\end{array}$} & SC1 & $\begin{array}{l}\text { Current information systems satisfy supply chain communication } \\
\text { requirements }\end{array}$ \\
\hline & $\mathrm{SC} 2$ & $\begin{array}{l}\text { Information applications are highly integrated within the firm and } \\
\text { supply chain }\end{array}$ \\
\hline & $\mathrm{SC} 3$ & $\begin{array}{l}\text { Adequate information systems linkages exist with supply chain } \\
\text { partners }\end{array}$ \\
\hline \multirow{5}{*}{$\begin{array}{l}\text { Information } \\
\text { sharing } \\
\text { (IS) }\end{array}$} & IS1 & $\begin{array}{l}\text { Our organization exchanges relevant information with the } \\
\text { partners }\end{array}$ \\
\hline & IS2 & Our organization exchanges timely information with the partners \\
\hline & IS3 & Our organization exchanges accurate information with partners \\
\hline & IS4 & $\begin{array}{l}\text { Our organization exchanges confidential information with } \\
\text { partners }\end{array}$ \\
\hline & IS5 & $\begin{array}{l}\text { Our organization exchanges confidential information with } \\
\text { partners }\end{array}$ \\
\hline \multirow{2}{*}{$\begin{array}{l}\text { Supply chain } \\
\text { visibility } \\
\text { (SCV) }\end{array}$} & SCV1 & Inventory levels are visible throughout the supply chain \\
\hline & SCV2 & Demand levels are visible throughout the supply chain \\
\hline \multirow{3}{*}{$\begin{array}{c}\text { Product } \\
\text { complexity } \\
(\mathrm{PC})\end{array}$} & PC1 & $\begin{array}{l}\text { We offer our customers diverse add-ons and the option of } \\
\text { production individualization }\end{array}$ \\
\hline & PC2 & Our product consists of a high number of components \\
\hline & PC3 & We frequently offer new product variants \\
\hline \multirow{10}{*}{$\begin{array}{c}\text { Social } \\
\text { performance } \\
\text { (SP) }\end{array}$} & SP1 & Our organization believes in gender equality \\
\hline & SP2 & $\begin{array}{l}\text { Our organization pays significant attention to the mortality rate of } \\
\text { the daily wage workers children }\end{array}$ \\
\hline & SP3 & Our organization believes in poverty reduction \\
\hline & SP4 & $\begin{array}{l}\text { Our organization pays significant attention to the nutritional status } \\
\text { of the meal served in the canteen }\end{array}$ \\
\hline & SP5 & $\begin{array}{l}\text { Our organization pays significant attention to the sanitation at } \\
\text { work place, offices and lavatories }\end{array}$ \\
\hline & SP6 & Our organization ensures adequate safe drinking water facility \\
\hline & SP7 & $\begin{array}{l}\text { Our organization pays significant attention to effective health care } \\
\text { delivery }\end{array}$ \\
\hline & SP9 & Our organization helps to find proper residence for employees \\
\hline & SP10 & $\begin{array}{l}\text { Our organization provides adequate transport facility from } \\
\text { residence to the work-place }\end{array}$ \\
\hline & SP11 & $\begin{array}{l}\text { Our organization pays significant attention to the living conditions } \\
\text { of the employees }\end{array}$ \\
\hline \multirow{2}{*}{$\begin{array}{l}\text { Environmental } \\
\text { performance } \\
\text { (EP) }\end{array}$} & EP1 & $\begin{array}{l}\text { Our organization has adopted adequate measures for reduction of } \\
\text { air emissions }\end{array}$ \\
\hline & EP2 & $\begin{array}{l}\text { Our organization has adopted adequate measures for re-cycling } \\
\text { waste water }\end{array}$ \\
\hline
\end{tabular}




\begin{tabular}{|c|l|l|}
\multirow{4}{*}{} & EP3 & $\begin{array}{l}\text { Our organization has adopted adequate measures to prevent } \\
\text { discharge of solid waste }\end{array}$ \\
\cline { 2 - 3 } & EP4 & $\begin{array}{l}\text { Our organization has adopted adequate measures to prevent } \\
\text { consumption of hazardous harmful toxic materials }\end{array}$ \\
\cline { 2 - 3 } & EP5 & $\begin{array}{l}\text { Our organization has adopted adequate measures to reduce the } \\
\text { frequency of environmental accidents }\end{array}$ \\
\cline { 2 - 3 } & EP6 & $\begin{array}{l}\text { Our organization has made a significant effort to improve an } \\
\text { enterprise's environmental situation }\end{array}$ \\
\hline \multirow{4}{*}{$\begin{array}{c}\text { Economic } \\
\text { performance } \\
(\text { ECOP })\end{array}$} & ECOP1 & Decrease of cost for materials purchasing \\
\cline { 2 - 3 } & ECOP2 & Decrease of cost for energy consumption \\
\cline { 2 - 3 } & ECOP3 & Decrease of fee for waste treatment \\
\cline { 2 - 3 } & ECOP4 & Decrease of fee for waste discharge \\
\cline { 2 - 3 } & ECOP5 & Decrease of fine for environmental accidents \\
\hline
\end{tabular}


Appendix 2: Exploratory Factor Analysis

\begin{tabular}{|c|c|c|c|c|c|c|c|c|}
\hline & ECOP & PC & SCV & IS & SP & SC & EP & \\
\hline SC1 & & & & & & 0.74 & & \\
\hline SC2 & & & & & & 0.80 & & \\
\hline SC3 & & & & & & 0.78 & & \\
\hline IS1 & & & & 0.59 & & & & \\
\hline IS2 & & & & 0.88 & & & & \\
\hline IS3 & & & & 0.88 & & & & \\
\hline IS4 & & & & 0.97 & & & & \\
\hline \multicolumn{9}{|l|}{ IS5 } \\
\hline SCV1 & & & 0.90 & & & & & \\
\hline SCV2 & & & 0.90 & & & & & \\
\hline PC1 & & 0.91 & & & & & & \\
\hline PC2 & & 0.90 & & & & & & \\
\hline PC3 & & 0.98 & & & & & & \\
\hline SP1 & & & & & 0.69 & & & \\
\hline SP3 & & & & & 0.80 & & & \\
\hline SP4 & & & & & 0.85 & & & \\
\hline SP5 & & & & & 0.81 & & & \\
\hline SP6 & & & & & 0.87 & & & \\
\hline SP7 & & & & & 0.95 & & & \\
\hline SP9 & & & & & 0.56 & & & \\
\hline SP10 & & & & & 0.61 & & & \\
\hline SP11 & & & & & 0.69 & & & \\
\hline \multicolumn{9}{|l|}{ SP12 } \\
\hline EP1 & & & & & & & 0.87 & \\
\hline EP2 & & & & & & & 0.68 & \\
\hline EP3 & & & & & & & 0.89 & \\
\hline EP4 & & & & & & & 0.85 & \\
\hline EP5 & & & & & & & 0.81 & \\
\hline EP6 & & & & & & & 0.79 & \\
\hline ECOP1 & 0.94 & & & & & & & \\
\hline ECOP2 & 0.95 & & & & & & & \\
\hline ECOP3 & 0.94 & & & & & & & \\
\hline ECOP4 & 0.93 & & & & & & & \\
\hline ECOP5 & 0.94 & & & & & & & \\
\hline & 4.42 & 2.60 & 1.63 & 2.84 & 5.33 & 1.79 & 4.02 & 22.64 \\
\hline & 12.29 & 7.23 & 4.54 & 7.90 & 14.81 & 4.96 & 11.18 & \\
\hline
\end{tabular}

